Int. J. Dev. Biol. 52: 147-150 (2008)

doi: $10.1387 / \mathrm{ijdb} .072330 \mathrm{zb}$

\title{
Bronislawa and Mieczyslaw Konopacki - pioneers of the application of histochemistry to embryology in Poland
}

\author{
ZOFIA BIELANSKA-OSUCHOWSKA* \\ Department of Histology and Embryology, Faculty of Veterinary Medicine, Warsaw Agricultural University, Warsaw, Poland
}

\begin{abstract}
In this paper, we review the life and work of Mieczyslaw Konopacki and his wife Bronislawa Konopacka. These Polish scientists introduced histochemical methods to embryological studies at the beginning of the XXth century; they were pioneers in this regard in Poland and among the first in the world to implement such methods in this way.
\end{abstract}

KEY WORDS: B. Konopacka, M. Konopacki, embryology, histochemistry

At the beginning of the last century, the transformation of embryology from a purely descriptive to an experimental discipline studying the mechanisms of development, marked the turning point in embryological research. For the first time, artificial insemination of echinoids was introduced and the first surgeries (manipulations) were performed on animal embryos. Polish scientists made a significant contribution to these pioneering studies. An important centre of embryological research was the Department of Human Anatomy at the Jagiellonian University in Krakow (Eng.: Cracow) headed by Kazimierz Kostanecki and later by Emil Godlewski Jr. (see Sliwa, 2008, pp.97-100 in this issue). Bronislawa Konopacka ${ }^{1}$ and Mieczyslaw Konopacki graduated from this centre.

The Konopackis were born at the end of the $19^{\text {th }}$ century, at the time when Poland was absent from the map of Europe, partitioned between three neighbouring countries: Russia, Prussia and Austria. Konopackis survived the First World War, lived in the independent Poland and Mrs Konopacka survived also the Second World War to spend her last years under the difficult conditions of the post-war Poland dominated by the Soviet Union.

Mieczyslaw Konopacki was born in 1980 in Wielun, near Lodz, under Russian rule. Since 1916 he had been a Professor and a Head of the Histology and Embryology Department at the Faculty of Medicine of the Warsaw University. He was a member of the Polish Academy of Arts and Sciences (Krakow), and a founder of the Polish Anatomical Society. He was killed by a bomb on September 25, 1939 on the street of Warsaw during its siege by Germans.

Bronislawa Konopacka, a daughter of a doctor, W. Jakimowicz, was born on October the $1^{\text {st }}, 1884$ in Juriew Polski. She spent her childhood and adolescence in Piotrkow Trybunalski, which at that time was under the Russian rule. She graduated from a private school for girls named after P. Hewelke, in Warsaw, and in 1902 she passed a state examination as an extern at the state school for boys in Piotrkow Trybunalski. In 1903 she was accepted by the Jagiellonian University in Krakow as a special student. She could not enroll as a regular student because, at that time, women did not have the right to study at universities. and in addition, her high school diploma acquired in the Russian occupied part of Poland, was not recognized in the Austrian occupied part, where the Jagiellonian University was located. She studied natural sciences at the Philosophical Faculty and graduated in 1907. However, being a woman, she did not have a right to receive the scientific title of the Master of Natural Sciences. All scientific titles (M,Sc., Ph.D., D. Sc. and professor) she received after the Second World War.

A capable and diligent student she quickly drew the professors' attention. As a third year student she started research in the embryological laboratory headed by Professor. Emil Godlewski Jr. In that laboratory she met Mieczyslaw Konopacki, a young physician, whom she married in 1907. They both moved to Lwow (presently 'Lvov' in Ukraine) where M. Konopacki became an assistant in the Department of Histology of the Lwow University headed by Professor Wladyslaw Szymonowicz, and she worked there as a volunteer. They often traveled and worked abroad in the biological stations in Trieste and Naples carrying out embryological studies on invertebrates and fish (Konopacki, 1911, 1912, 1914, 1918). In 1910 Bronislawa Konopacka completed a course on marine zoology at the biological station in Trieste. In the years 1912-1913 they both worked abroad, first under Professor Heider

*Address correspondence to: Zofia Osuchowska. Zaklad Histologii i Embriologii, SGGW, ul. Nowoursynowska 159, 02-776 Warszawa, Poland. e-mail: zofia.osuchowska@wp.pl

Note 1: In Polish, the name of the husband is Konopacki, whereas the name of his wife is Konopacka. 

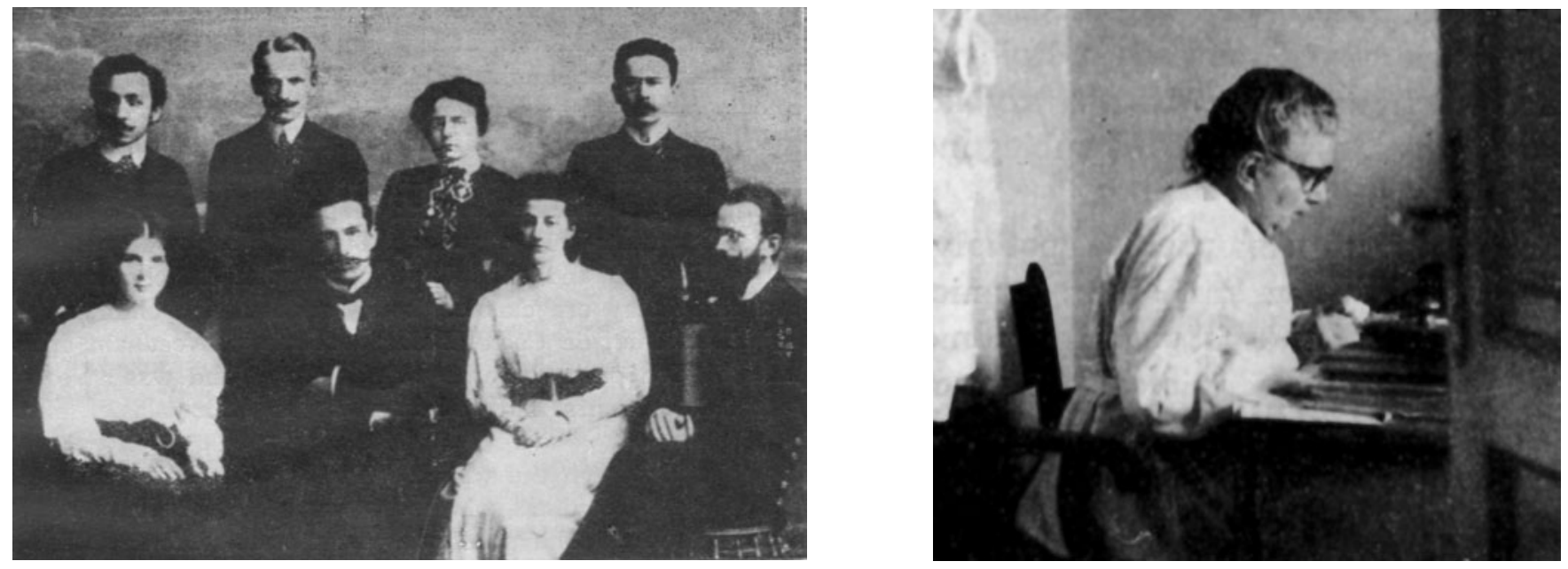

Fig. 1 (Left). Photo taken in the Department of Human Anatomy at the Jagiellonian University in Krakow around 1910. From let to right; standing: Kazimierz Bialaszewicz, J. Mlodkowski, Zofia Radwanska- Kiernik and Mieczyslaw Konopacki; sitting: Bronislawa Konopacka, Emil Godlewski Jr.,Zofia Wyrzykowska-Michejdzina and Michal Siedlecki.

Fig. 2 (Right). Prof. Bronislawa Konopacka in the laboratory of the Department of Histology and Embryology of the Faculty of Veterinary Medicine, Warsaw Agricultural University (1960).

in Insbruck in Austria, and then in the biological station in Villefranche-sur-Mer in France. The First World War stopped their work and destroyed the whole collection of samples of Patella snail oogenesis collected by Bronislawa Konopacka in Villefranche. During the World War I Mrs. Konopacka worked for social organizations helping the war victims. In 1916, Mr. and Mrs. Konopacki moved to Warsaw where a new Department of Histology was opened at the Faculty of Medicine of the Warsaw University. Mr. Konopacki was offered the post of the Head of this new Department. Mrs. Konopacka participated in her husband scientific and didactic work preparing material for student classes: histological slides, tables and other teaching aids. Again she worked as a volunteer, because, at that time, it was unacceptable that a professor's wife could work full time. In 1930 and $1934 \mathrm{Mr}$. and Mrs. Konopacki did their research at the biological station in Naples.

The Second World War brutally interrupted the life of Mr. and Mrs. Konopacki. Mieczyslaw Konopacki, who then worked as a physician, was killed on the street of Warsaw during the bomb attack on the $25^{\text {th }}$ of September, 1939. The building that housed the Department of Histology was seriously damaged during the war. Despite her personal tragedy and the loss of lodgings and all personal possessions, Mrs. Konopacka worked energetically at saving the Department from destruction by the Nazi. Together with a few employees who remained in Warsaw she protected the library and part of the teaching materials. However, it was impossible to save the collection of scientific samples.

Mrs. Konopacka spent the World War II in Warsaw. To survive with her two daughters, Mrs. Konopacka started to work in the Parasitology Department of the State Institute of Hygiene. Since schools and Universities were closed by the German invaders, the authorities of the Polish underground organized the clandes- tine teaching. Bronislawa Konopacka was one of the first who participated in the teaching of medical students of the underground Warsaw University and the University of Western Territories $^{2}$ that was located also in Warsaw. The studies were secretly organized in the dr. Zaorski school for auxiliary medical staff. Mrs. Konopacka lectured and, using the slides saved from the destroyed Department of Histology and Embryology of the Faculty of Medicine of the Warsaw University, conducted histology and embryology classes. Because the public libraries were closed down and seized by the invaders, and many private book collections were destroyed, Mrs Konopacka prepared her lectures from the Florian embryology text book, in the Czech language, the only text book available Mrs. Konopacka did not know the language, so she had to read it with a dictionary, translating word by word.

Displaced by Germans from Warsaw in the autumn of 1944 after the fall of the Warsaw Upraising, she went to Zakopane. However, already in June 1945, i.e. right after the end of the war, she came back to work in the State Institute of Hygiene, which was re-established in Lodz. At the same time she started to work in the newly created Department of Histology and Embryology, at the Faculty of Medicine of the Lodz University.

In January 1948, already as D.Sc. (a degree next to Ph.D, equivalent of German and Austrian 'docent'), she came back to Warsaw, to the Department of Histology and Embryology, at the Faculty of Medicine of the Warsaw University where she had lectures and classes for students. In 1949 she became a corresponding member of the Warsaw Scientific Society (a counterpart of the Academy of Arts and Sciences in Krakow). In 1952 Mrs. Konopacka was invited to head the Department of Histology and Embryology at the Faculty of Veterinary Medicine, Warsaw Agricultural University. Formally, she headed the Department until she retired in 1960, but in practice until her death in 1965. In 1955

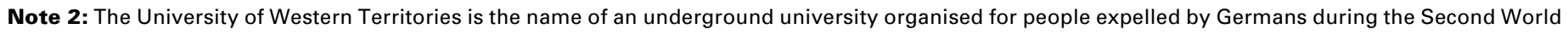
War from the western territories of Poland. 
she received the title of extraordinary professor.

As it has already been mentioned, Mrs. Konopacka started her scientific career already as a student of the third year. She studied the development of amphibian embryos. Her first paper published in 1908 (Konopacka, 1908) described the effect of centrifugation on the development of the frog embryo. She showed that, if the centrifugation was performed prior to the appearance of the third cleavage, the displacement of the yolk caused the discoidal cleavage in amphibian

Mr. and Mrs. Konopacki as the first in Poland, and one of the first in the world introduced histochemical methods to embryology. They studied the origin and the composition of yolk in the oogenesis of cephalopods (Loligo) (Konopacki,1933), fish (Konopacka, 1935, 1937, 1939), amphibians (Konopacka, 1924a; Konopacki, 1923, 1924b,c; Konopacki and Konopacka, 1926) and birds (Konopacka, 1932,1933). They noticed that in these animals the vitellogenesis was preceded by the increased activity of the cell nucleus and intensification of basophilia of the cytoplasm, and that numerous nucleoli bulged from the cell nucleus to the cytoplasm in fishes (Konopacka, 1935). They demonstrated that despite the differences in morphology and the composition of yolk platelets, in all the investigated species, first the lipids and subsequently yolk platelets (containing proteins, lipids and glycoproteins) appear in the oocyte during vitellogenesis. Glycogen is produced as the last component of the reserve substances (Konopacki and Konopacka, 1926; Konopacki, 1933; Konopacka, 1935). They also studied the role of follicular epithelium in the transport of substances, produced outside the ovary, to the oocyte, and in the formation of egg envelopes (Konopacki, 1933).

Mr. and Mrs. Konopacki were interested not only in the formation of the reserve substances in the egg but also in their utilization by the developing embryo. They studied the localization of lipids and glycogen in embryonic development. They suggested that

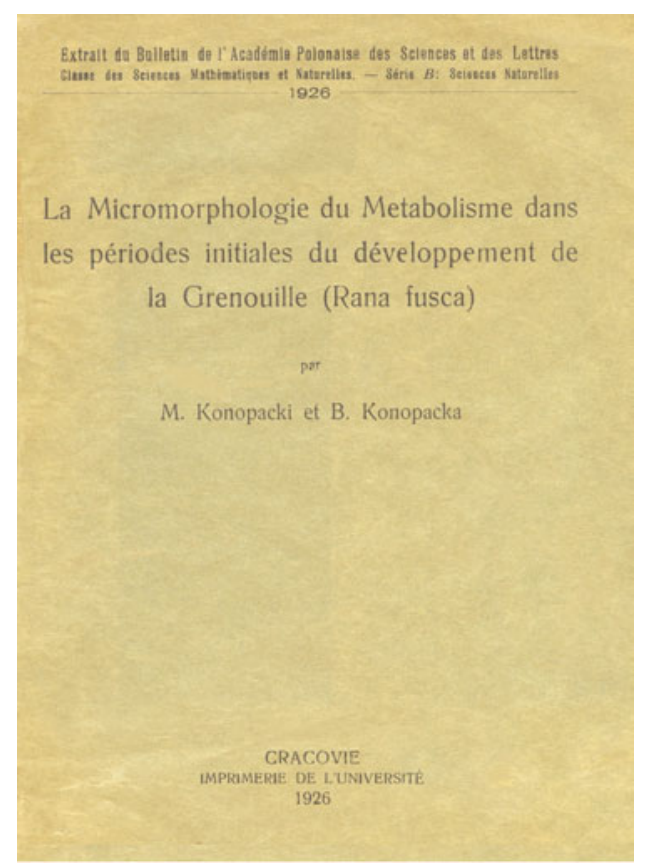

Fig. 3. Cover of the Konopacki paper from 1926. The title of the paper, published in French reads "The micromorphology of metabolism during the initial developmental stages of the frog (Rana fusca). "
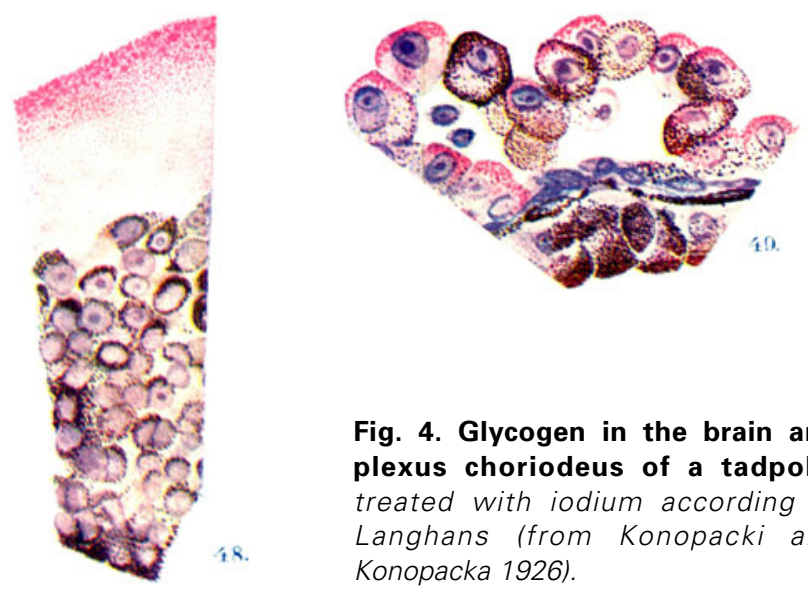

Fig. 4. Glycogen in the brain and plexus choriodeus of a tadpole, treated with iodium according to Langhans (from Konopacki and Konopacka 1926).

various enzymes, including at least two diastases, take part in the processes of decomposition and utilization of the yolk (Konopacki, 1933). They noticed that in the frog, the reserve substances accumulated in the yolk, are used by the embryo, starting from the gastrulation stage. In the embryonic cells, the yolk platelets are broken down into protein and fat components. Protein substances are used first and the fat material is used next. Lipids are fully utilized only during histogenesis. In particular germ layers and organs the disintegration of yolk occurs at different time and with different rate. There is also a cranial-caudal and dorsal-ventral gradient in the spacing of lipids and the rate of their disintegration (Konopacki and Konopacka, 1926).

At that time many observations by Mr. and Mrs. Konopacki were a complete novum in embryology. For the first time they described "glycogeno-proteique complexes", the small granules in the cortical cytoplasm of oocytes stained with Best carmine that, however, did not react with iodine which stains glycogen (Konopacki, 1936). In the frog (Konopacki and Konopacka, 1926) and fish (Konopacka, 1935), after the spermatozoa enter the egg, the granules are extruded on the surface of eggs, and form a glyco-protein layer in the perivitelline space that corresponds to the fertilization membrane in echinoids. Later this phenomenon was named cortical reaction. Mr. and Mrs. Konopacki were not able to interpret all their observations. They wondered why with the development of oogenesis cell nuclei became gradually "achromatic" - i.e gradually Feulgen-negative (Konopacki and Konopacka, 1926; Konopacki, 1933, Konopacka, 1936) [as we now know this is partially due to despiralization of chromosomes during diplotene], and why in some animals, such as ascidia, Feulgen-positive reaction appeared in the oocyte cytoplasm in the form of small granules (Konopacki 1936) [as we now know this is due to the presence of DNA in mitochondria].

After joining the Faculty of Veterinary Medicine of the Warsaw Agricultural University Mrs. Bronislawa Konopacka started research on organogenesis of mammalian embryos. She demonstrated that using histochemical methods it is possible to detect the moment of the beginning of the function of the developing organ. Each differentiating organ, or even its particular parts, have their own rhythm of transformation, which can be detected using the histochemical methods. For example the alkaline phosphatase is first activated at the beginning of the differentiation of the tissues specific for a particular organ, and then is activated for 
the second time at the moment when the organ starts to function (Konopacka, 1955, 1959a,b, 1960, 1963,1964).

During the last years of her life Professor Konopacka devoted herself to research of oogenesis and the embryonal development of Nereis diversicolor. Some of these studies focused on the role of alkaline phosphatase in fertilization and early embryonal development of this worm. Phosphatase appears in the late gastrula in the cells, which will later develop into the mesoderm (Konopacka and Szankowska, 1962). Another area of research involved the role of nucleoli in oogenesis. Professor Konopacka prepared a presentation for the Meeting of the Polish Anatomical Society in Olsztyn in 1965. Sadly, her sudden death did not allow her to present this report or to publish it.

The classic research of Professsors Konopacki and Konopacka, and especially that of Konopacka, is quoted in the textbooks on embryology and biology by such authors as J. Brachet, da Costa, Dalcq, Needham or Raven.

Appreciating the significance of histochemical methods in biological studies and in medicine, Professor Bronislawa Konopacka, who was the President of the Polish Anatomical Society, organized in the Society a histochemical section, which in 1961 was transformed into a Polish Histochemical and Cytochemical Society.

\section{References}

KONOPACKA, B. (1908). Die Gestaltungsvorgänge in verschiedenen Entwicklungsstadien zentrifugierten Froschkeime. Bull. de l'Acad des Sciences de Cracovie: 690-741,

KONOPACKI,M. (1911). Über den Einfluß hypertonischer Losungen auf befruchte Echinideneier. Arch. f. Zellforschung 7:

KONOPACKI, M.(1912). Über mikroskopische Veränderungen, welche während der in Echinideneiern mittels verschiedener chemischer Reagenzien hervorgerufenen Cytolyse auftreten. Bull. de l'Acad. des Sciences de Cracovie: 527-562,

KONOPACKI, M.(1914). Über die Einfluß des verdunnten Seewassers auf verschiedene Entwicklungsstadien der Echinideneier. Bull. de l'Acad.Sciences de Cracovie: $5515-525$.

KONOPACKI, M..(1918). Untersuchungen uber die Einwirkung verdunten Seewassers auf verschiedene Entwicklungsstadien der Echinoideen. Arch.f Entwicklungsmech. 44.

KONOPACKI, M..(1923). Analyse microchimique de la substance perivitellin dans les oeufs de Grenouille, Comp. Rend. Soc. Biol. 90: 593-595.

KONOPACKI, M. (1924). Influence de l'eau destilée sur le développement des oeufs de Grenouille. Bull.d'Hist.appl. 1:7-28.

KONOPACKI, M. (1924). Quelques données histochimiques sur le noyau vitellin et sur la formation du vitellus dans les oocytes de la Grenouille. Comp. Rend. Soc. Biol. 92: 372- 374

KONOPACKA, B. (1924). Sur !es graisses et lipoides dans le développement des embryons de la grenouille. Comp. Rend. Soc. Biol. 92: 971-972.

KONOPACKI, M., KONOPACKA, B. (1926). La micromorphologie du métabolisme dans les périodes initiales du développement de la gernouille, [Rana fusca]. Bull. Acad. Polon. Scie. Lett: 229-291.

KONOPACKI, M. (1927). Sur le comportement des mitochondries au cours du développement de la Grenouille. Bul.d' Histol. appl. 4: 40-50.

KONOPACKA, B. (1932). Le comportement des graisses dans le développement de la Poule. Bull. Acad. Polon. Scie. Lett: 643-648.

KONOPACKA, B. (1933). Etude microchimique du comportement de la graisse dans le procesus de la formation du vitellus et dans le developpment de l' embryon de Poule. Arch. Biol. 44:,251-305.

KONOPACKI, M. (1933). Histophysiologie du développment de Loligo vulgaris. Bull. Acad. Polon. Scie. Lett: 51-69.

KONOPACKA, B. (1935). Recherches histochimiques sur le developpment des poissons: I. La vitellogenese chez le goujon et la carpe / Gobio flviatilis et Cyprinus carpio/. Bull. Acad. Polon. Scie. Lett: 163-1883.,

KONOPACKI, M. (1936). Organizacja komorki jajowej (Organization of the egg cell), Folia Morph. 7: 1-15.

KONOPACKA, B. (1937). Recherches histochimiques sur le dveloppment des poissons: II. La vitellog nese chez certains Teleosteens de mer, (Gobius paganellus, Smaris alcedo, Crenilabrus pavo et Atherina Boyeri et Atherina hepsetus). Publicationi di Stazione Zoologca Napoli 16: 327-362.

KONOPACKA, B. (1939). La formation de la symetrie bipolaire dans les ouefs de certains poissons osseux (Gobius paganellus, Smaris Alcedo, Crenilabrus pavo i Atherina hepsetus). Bull. Acad. Polon. Scie. Lett: 341-349.

KONOPACKA, B. (1955). Alkaline phosphatase in the intestinal epithelium of the pig embryos. Folia Morph. 6: 193- 2201.

KONOPACKA, B. (1959). Histochemical changes during the process of intestinal epithelium differentiation in the pig embryo, Folia Morph. 10: 1-8.

KONOPACKA, B. (1959). Phosphatases in early embryo development and in organogenesis. Post. Hig. Med. Dosw. 13: 179-197.

KONOPACKA, B. (1960). Lipids in the intestine epithelium of the domestic pig embryos. Folia Morph. 11: 247- 250.

KONOPACKA, B., Szankowska,Z. (1962). Role of alkaline phosphatase in fertilization and early development of Nereis diversicolor. Folia Morph. 21: 715- 723.

KONOPACKA, B. (1963). The acivity of alkaline phosphatase in the devlepoment and function of mesonephros in embryo of the domestic pig. Folia Biol. 118: 1930.

KONOPACKA, B. (1964). The sequence of apearence of certain chemical substances and cytological changes in the cells of the metanephros of the domestic pig during its development, function and involution. Folia Histoch.Cytoch. 2: 141-155.

SLIWA, L. (2008). Emil Godlewski, Jr. (1875-1944) pioneer of embryology at the Jagiellonian University of Krakow (Poland). Int. J. Dev. Biol. 52: 97-100.

\section{RELATED SPECIAL ISSUES}

See our recent Special Issue Developmental Biology in Poland edited by Kloc, Maleszewski and Tarkowski at:

http://www. ijdb.ehu.es/web/contents. php?vol=52\&issue=2-3

See our Special Issue Mammalian Reproduction \& Development in honor of Anne McLaren and edited by Brigid Hogan at: http://www.ijdb.ehu.es/web/contents.php?vol=45\&issue=3

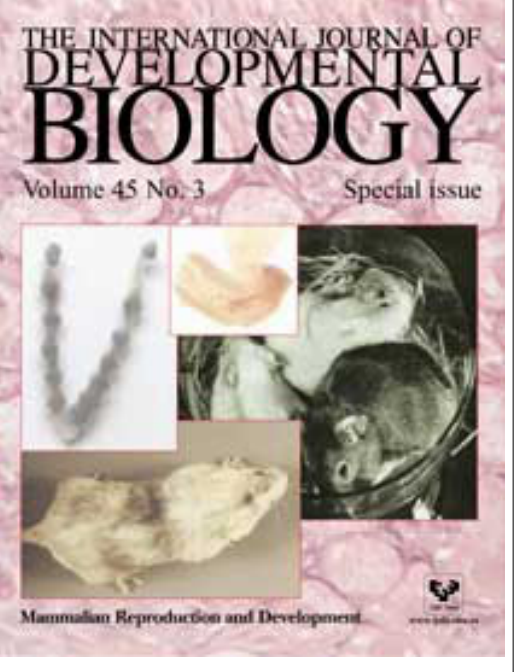

